\title{
The Reliability of DIVA Test Based on M2e Peptide Exceed Those Based on HA2 or NS1 Peptides
}

\author{
Tarigan $\mathrm{S}^{1}$, Sumarningsih ${ }^{1}$, Ignjatovic $\mathrm{J}^{2}$ \\ ${ }^{1}$ Balai Besar Penelitian Veteriner, Jl RE Martadinata 30 Bogor 16114 \\ ${ }^{2}$ Faculty of Veterinary Science, University of Melbourne, Victoria 3010, Australia \\ E-mail:simsont@me.com \\ (received 13-03-2015; revised 10-06-2015; accepted 17-06-2015)
}

\begin{abstract}
ABSTRAK
Tarigan S, Sumarningsih, Ignjatovic J. 2015. Reliabilitas tes DIVA berbasis M2e jauh lebih tinggi dibandingkan dengan tes DIVA berbasis HA2 atau protein NS1. JITV 20(2): 126-133. DOI: http://dx.doi.org/10.14334/jitv.v20i2.1167

Salah satu kelemahan utama vaksinasi pada avian influenza adalah bahwa vaksinasi tersebut tidak dapat memberikan perlindungan terhadap infeksi. Bila peternakan yang menerapkan vaksinasi terpapar virus dalam jumlah besar, infeksi subklinis dapat menyebar dalam peternakan tersebut dalam waktu yang lama tanpa diketahui. Kondisi tersebut hanya dapat dimonitor dengan alat tes DIVA (differentiation of infected from vaccinated animals), alat uji konvensional tidak dapat digunakan. Tes DIVA berdasarkan antibodi yang terbentuk akibat stimulasi virus bereplikasi merupakan tes DIVA yang paling sesuai. Untuk influenza H5N1 antibodi yang dimaksud antara lain antibodi terhadap M2e, protein NS1 dan peptida HA2 (HA_488-516). Tujuan penelitian ini adalah membandingkan level antibodi terhadap peptida M2e, NS1 dan HA2 pada ayam normal, vaksinasi dan infeksi (1, 2-3, $\geq 4$ minggu pasca infeksi). Level antibodi diukur dengan ELISA menggunakan sintetik peptida sebagai antigen koting. Peptida yang digunakan antara lain: 4 buah peptida NS1 yang didasarkan pada berbagai lokasi pada protein NS1, peptida M2e dan HA2. Semua peptida dibiotinilasi pada ujung N nya. Koting peptida pada microtitre plate dilakukan secara langsung atau melalui jembatan streptavidin. Penelitian ini menunjukkan bahwa vaksinasi tidak merangsang pembentukan antibodi terhadap semua peptida. Ayam yang terinfeksi membentuk antibodi dengan level yang tinggi terhadap peptida M2e, tetapi sangat rendah terhadap peptida NS1 dan HA2. Antibodi terhadap peptida NS1 dan HA2 hanya dapat dideteksi dengan ELISA streptavidin-peptida. ELISA berbasis NS1 atau HA2 tidak dapat diandalkan sebagai tes DIVA untuk penyakit AI H5N1 pada ayam.
\end{abstract}

Kata Kunci: M2e, Protein NS1, Peptida HA2, Tes DIVA, H5N1

\section{ABSTRACT}

Tarigan S, Sumarningsih, Ignjatovic J. 2015. The reliability of DIVA test based on M2e peptide exceed those based on HA2 or NS1 peptides. JITV 20(2): 126-133. DOI: http://dx.doi.org/10.14334/jitv.v20i2.1167

One of the most important disadvantage of vaccination against avian influenza is that it cannot protect vaccinated birds against infection. When vaccinated poultry are heavily exposed to the virus, prolonged, unrecognised, subclinical infection may persist on the farm. The condition can only be serologically monitored by a DIVA (differentiation of infected from vaccinated animals) test, whereas conventional diagnostic tests cannot be used. The DIVA tests based on an antibody response following virus replication is the most appropriate approach. For H5N1 influenza such antibodies includes those to the M2e and NS1 proteins and an epitope on the HA2 subunit (HA_488-516). The purpose of this study was to compare the magnitude of the antibody response in chickens vaccinated and infected with an H5N1 virus strain. For that purpose, sera collected from naïve, vaccinated and infected birds, at 1, 2-3, $\geq 4$ weeks post challenge were used. Antibodies were measured by ELISA using biotinylated synthetic peptides as coating antigens. The peptides used include four NS1 peptides corresponding to different regions of the NS1 protein and HA_488-516and M2e peptides. Peptides were coated onto microtitre plates either directly or via a streptavidin bridge. The results showed that vaccination did not cause antibody conversion to any of the peptides, where as challenged birds developed a high antibody response to M2e but, low response to the NS1 and HA2 peptides. Antibodies to the later peptides were detected only by the streptavidin-peptide ELISA. The ELISA based on NS1 or HA_488-516 peptides, therefore, are not reliable for use as DIVA test in H5N1 avian influenza virus infection.

Key Words: M2e, NS1 Protein, HA2 Peptide, DIVA Test, H5N1

\section{INTRODUCTION}

One of the most important draw backs of avian influenza vaccination in poultry is the difficulty in disease surveillance. Vaccination provides protection against clinical disease and reduces the amount of virus shed by the infected birds, but it cannot provide complete protection against virus infection (Savill et al. 
2006). When a vaccinated flock is exposed to HPAI virus challenge, it may result in subclinical infection that continues to circulate in the flock unrecognized by the farmers. This situation is compounded by the fact that a practical diagnostic tool is not available that can be used to detect the presence of subclinical infection. The common serological test such as HI test, ELISA or Agar gel precipitation test could not be used, as they are unable to differentiate between antibodies in birds due to infection and those due to vaccination. Virus isolation, PCR or rapid antigen detection test are either too expensive or insensitive.

Serological test that can identify infected among vaccinated birds are termed DIVA (Differentiation of Infected from Vaccinated Animals) test. Different DIVA strategies for avian influenza have been reviewed previously (Suarez 2005; Tarigan 2015). DIVA strategy based on heterologous-neuraminidase was successfully applied in Italy (Capua et al. 2003; Capua et al. 2004) The prerequisite was that the vaccine used had to be generated from virus subtypes with neuraminidase heterologous to that of circulating virus, preventing the application of this strategy in other countries, including Indonesia. In addition, the indirect iFAT (fluorescent antibody test) used to identify infected birds in this strategy is also not practical.

Unlike DIVA test based on heterologousneuraminidase, DIVA test based on the external domain of $\mathrm{M} 2$ protein $(\mathrm{M} 2 \mathrm{e})$ is independent from the vaccine subtype since antibodies to M2e develop only in infected animals but not in vaccinated with killed AIV vaccines. ELISA based on either synthetic M2e peptide or bacterial expressed M2e protein has been used to measure the M2e antibody response (Lambrecht et al. 2007; Kim et al. 2010; Hemmatzadeh et al. 2013; Hadifar et al. 2014; Tarigan et al. 2015). The M2eELISA was reported to have high specificity but rather low sensitivity. The low sensitivity is attributed to the fact that M2e antibody can be detected in birds not sooner than 7 days of infection, and also some birds fail to seroconvert to M2e. Additional DIVA test capable of detecting infection in those M2e-negative, but infected birds, would be advantageous in order to increase the sensitivity of DIVA testing. The purpose of this study was to investigate the possibility of an ELISA test based on the influenza virus nonstructural-1 (NS1) protein and also on the recently identified epitope in the HA2 domain of haemagglutinin H5 (HA_488-516) as possible supplements to the M2e DIVA test (Khurana et al. 2011). This possibility was investigated by comparing the magnitude of the antibodies to those proteins or peptides in naïve, vaccinated and infected chickens.

The NS1 protein is the only true non-structural protein in Influenza viruses and interest in developing DIVA tests based on this protein have been considered.
However, the accuracy of test based on this protein as DIVA test is still contradictory between different studies. Some studies found that the NS1 based tests are sensitive and specific as DIVA test (Birch-Machin et al. 1997; Golchinfar et al. 2014; Ozaki et al. 2001; Takeyama et al. 2011), while others have found the reverse (Avellaneda et al. 2010). In this study, the accuracy of NS1-based ELISA as DIVA test was evaluated thoroughly by analyzing different fragments of the protein and different condition of ELISA. In addition, antibody to an epitope in the HA2 domain of haemagglutinin H5 (HA_488-516) suggested as being a reliable marker for $\mathrm{H} 5 \mathrm{~N} 1$ infection in human, has yet to confirmed in poultry (Khurana et al. 2011).

\section{MATERIALS AND METHODS}

\section{Peptide}

Four NS1 peptides, one HA peptide, and M2e peptide were synthesized by VCPBIO Inc. China. Following are the location and amino acid sequences of the peptides NS1_34-49 (Biotin-DRLRRDQKSLR GRGNT), NS1_23-42 (Biotin-ADQELGDAPFL DRLRRDQKS), NS1_87-98 (Biotin-TDMTLEEM SRDW), NS1_221-233 (Biotin-QKRKMARTIESEV), HA_488-516 (Biotin-DYPQYSEEARLKREEISG VKLESIGIYQI), M2e (Biotin-MSLLTEVETPTR NEWECRCSDSSD). All peptides, which were biotinylated at the N-terminal, had at least $90 \%$ purity.

\section{Serum}

Sera used in this study were collected from chicken experimentally infected with $\mathrm{H} 5 \mathrm{~N} 1$ influenza virus (A/Chicken/WestJava/Sbg-29/2007). The challenge experiment had been described in our previous study (Tarigan et al. 2015). Briefly, 200 layer chicken were divided into 4 groups (A, B, D and C). Groups A, B, and $\mathrm{D}$ were vaccinated with a commercial-killed-H5N1 vaccine 3, 2 and 1 times, respectively. Group $C$ birds were not vaccinated and served as a control. Two weeks after the last vaccination, randomly selected birds from each groups including the control were challenged with an isolate of $\mathrm{H} 5 \mathrm{~N} 1$ virus. For the current experiment, 18 sera from each group of pre-vaccination, post vaccination, 1, 2-3, and $\geq 4$ weeks post challenge were selected.

\section{Direct-peptided- and streptavidin-peptided-coated ELISA}

Two types of ELISA were used based on the method used for coating the peptides on the 96-well microtitre plate. In the first ELISA, each biotinylated peptide was disolved in carbonate buffer $(\mathrm{pH} 9.6)$ at 5 
$\mu \mathrm{g} / \mathrm{ml}$ then added to the plates at $100 \mu \mathrm{l} /$ well). After leaving at $4^{\circ} \mathrm{C}$ overnight, the plate was blocked with 5 $\mathrm{mg} / \mathrm{ml}$ of non-fat-skim milk in PBS ( $\mathrm{pH} \mathrm{7.2),} 150$ $\mu \mathrm{l} /$ well for 2 hours. Serum diluted at 1:100 in PBST(PBS, $0.5 \%$ Tween 20) supplemented with 5\% normal rabbit serum was added at $100 \mu \mathrm{l} /$ well, then incubated at $37^{\circ} \mathrm{C}$ for 2 hours. In each plate, negative control SPF chicken serum was added. After washing four times with PBST, HRP-rabbit-anti-chicken IgG conjugate (Sigma Co.) diluted 1:5000 in PBST supplemented with $5 \%$ normal rabbit serum was added, then incubated at $37^{\circ} \mathrm{C}$ for 2 hours. After washing four times with PBST, solution of substrate and chromogenic ABTS was added and the absorbance $\left(\mathrm{A}_{420}\right)$ measured with a spectrophotometer microtitre plate reader.

In the second type of ELISA, streptavidin disolved in carbonate buffer at $4 \mu \mathrm{g} / \mathrm{ml}$, was added $100 \mu \mathrm{l} /$ well, and left overnght at $4^{\circ} \mathrm{C}$. Streptavidin used in this study was produced in the previous study (Tarigan \& Sumarningsih 2014). After washing four times with PBST, biotinylated peptide diluted in PBS at $5 \mu \mathrm{g} / \mathrm{ml}$ was added at $100 \mu \mathrm{l} /$ well. The plate was blocked with skim milk and the remining procedures were the same as in the first type of ELISA.

A preliminary assay was carried out to prove that streptavidin coated to the plates did specifically bind to the biotin, and to determine the optimum concentration of streptavidin for the assay. Streptavidin was diluted to $4,2,1,0.5,0 \mu \mathrm{g} / \mathrm{ml}$ in carbonate buffer and added to mocrotitre plate at $100 \mu \mathrm{l} /$ well. After leaving at $4^{\circ} \mathrm{C}$ overnight, the plate was blocked with skim milk for 2 hours. Biotynilated chicken IgY, produced in the previus study (Tarigan et al. 2015), was added at 1:1600 and 1:3200 dilution in PBS and incubated at $37^{\circ} \mathrm{C}$ for 2 hours. After washing four times with PBST, HRP-anti chicken IgG (Sigma Co.) at 1: 5000 dilution was added and incubated at $37^{\circ} \mathrm{C}$ for 2 hours. After washing four times with PBST, solution of substrate and chromogenic ABTS was added and the absorbance $\left(\mathrm{A}_{420}\right)$ measured with a spectrophotometer microtitre plate reader.

\section{Statistical analysis}

The level of antibody, indicated by ELISA's OD, to each peptide in each group of bird (pre-vaccination, post-vaccination, 1-week-post challenge, 2-3-week-post challenge, and $\geq 4$-week-post challenge) was presented as the mean and $95 \%$ confidence interval of the mean of the ELISA's OD. Differences between groups were analised by one-way ANOVA (analysis of variance). All statistical analyses were carried out using a commercial statistical package $\quad\left(\right.$ IBM $^{\circledR} \quad$ SPSS $^{\circledR}$ Statistics).

\section{RESULTS AND DISCUSSION}

\section{Results}

Antibodies to NS1, HA_488-516 and M2e, measured by direct peptide ELISA in chickens of various immune or infection status, are presented in Figure 1. No antibody to any of the four NS1 peptides, the HA_488-516 peptide or M2e peptide was detected in chickens before and after vaccination. Antibody to M2e rose markedly after 1 week and remained high for several weeks after challenge. Unlike antibody to M2e, no antibody conversion was observed to any of the NS1 or HA_488-516 peptides.

There are two possibilities regarding the lack of measurable antibody conversion to the NS1 and HA2 peptides. The first possibility was that antibodies did not develop in those infected birds. This possibility seemed unlikely because antibody to NS1 should be detected whenever replication of influenza virus take place in immuno-competent animals. The strong antibody response to $\mathrm{M} 2 \mathrm{e}$ indicated that a substantial replication of $\mathrm{H} 5 \mathrm{~N} 1$ virus must have had taken place in those infected birds. The second possibility was that the direct peptide ELISA used in this study was not sensitive enough to detect the presence of NS1 or HA_488-516 antibodies. Onepossible cause of this insensitivity was that the NS1 and HA2 peptides did not bind to the plates, or were unable to bind the antibodies once the peptides were immobilised on the plates. This problem was aliviated by the use of the streptavidinpeptide ELISA.

When added to the streptavidin-coated, proteinblocked plates, biotinyl-IgY was bound to the plate efficiently. In contrast, no biotinyl-IgY was retained when added to a non-streptavidin-coated, proteinblocked plates (Figure 2). This results indicated that the binding activity of streptavidin coating was specific and efficient. The concentration of streptavidin on coated plates that maximally bound the biotinyl IgY was around $4 \mu \mathrm{g} / \mathrm{ml}$, and this concentration was used in all assays in this study. When the streptavidin-peptide ELISA was used to assay the chicken sera, the results, regarding antibody to $\mathrm{M} 2 \mathrm{e}$, were comparable to the direct peptide ELISA described above.

This streptavidin-peptide ELISA, however, was able to show that the level of antibody to all peptides in the sera of infected birds were higher than those in the non-infected birds (Figure 3). Although the increase of antibodies were only slight, they were statistically significant $(\mathrm{P}>0.05)$. The statistically significant increases or differences were between pre-vaccinated and challenged ( $\geq 4$ wpi), and post-vaccinated and challenged ( $\geq 4$ wpi) sera, to all peptides (Table 1 ). 


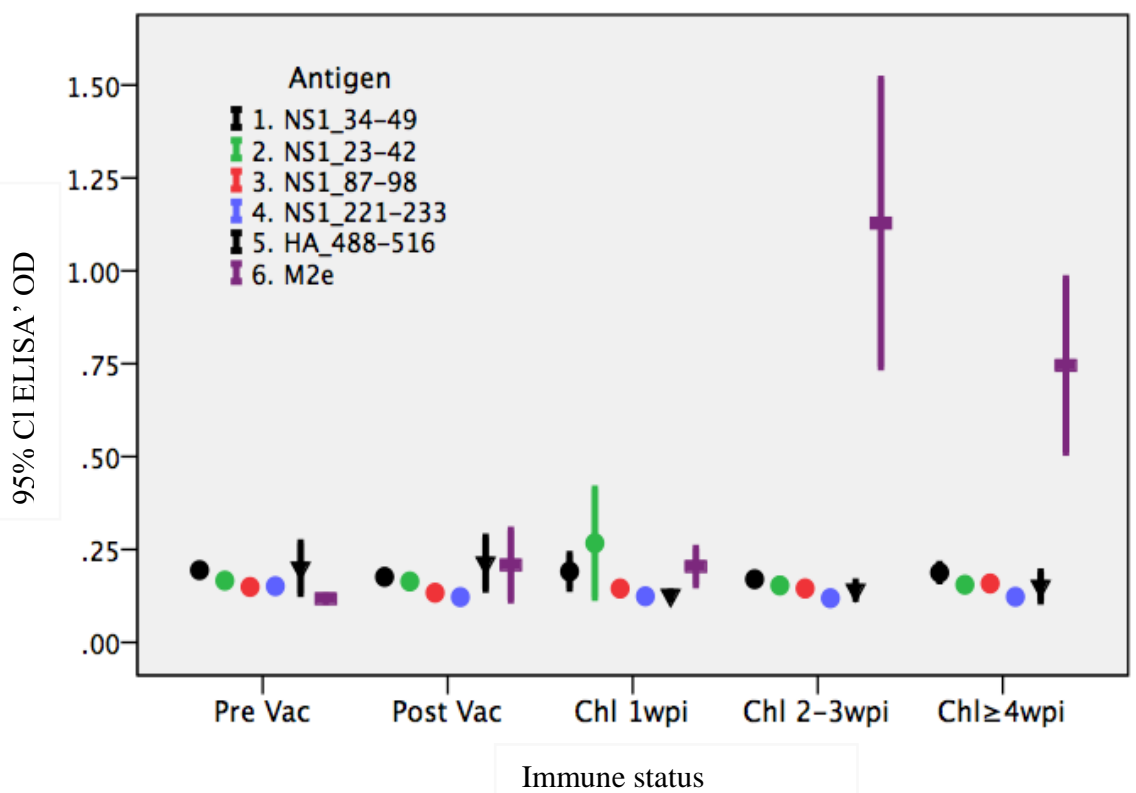
Pre Vac
$=$ Pre vaccination;
Post Vac = 2 week post vaccination (1,2 and 3 times vaccination);
Chl $1 \mathrm{wpi} \quad=1$ week post challenge;
Chl 2-3 wpi $=2$ and 3 weeks post challenge;
$\mathrm{Chl} \geq 4 \mathrm{wpi} \quad=4$ week or longer after infection or challenge

Figure 1. Antibody conversions to four NS1, HA_488-516 and M2e peptides in chickens after vaccination and challenge with H5N1 virus

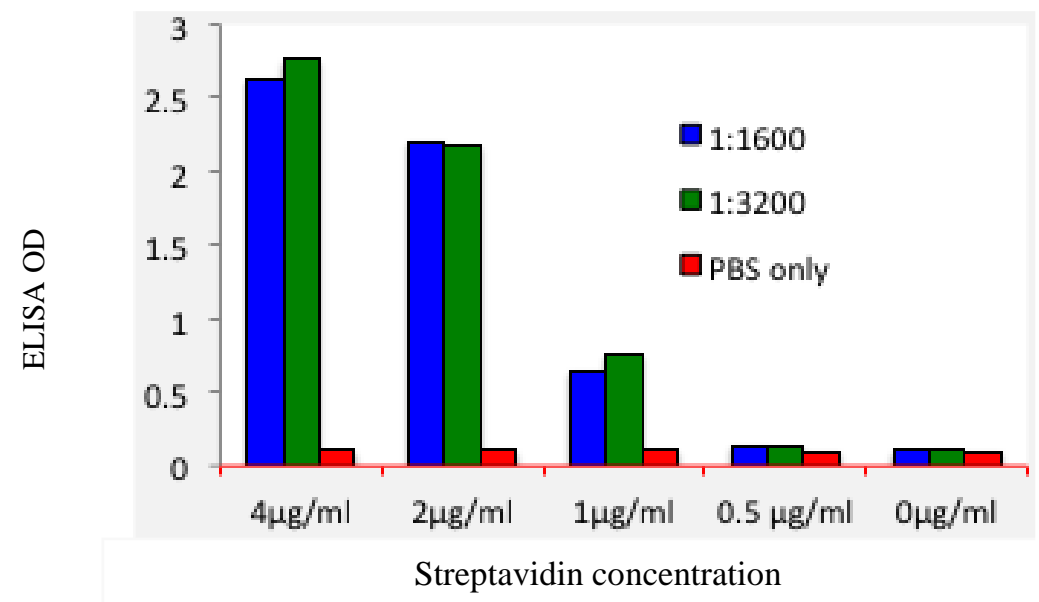

Figure 2. Binding of biotinylated IgY to streptavidin coated onto wells of microtitre plate. Biotinylated IgY was added to streptavidincoated, protein-blocked microtitreplate. The biotinylated IgY bound to streptavidin was detected by HRP-anti-chicken IgG and the quantity of biotinylated IgY bound to the strepatvidin was correlated with the ELISA's OD 


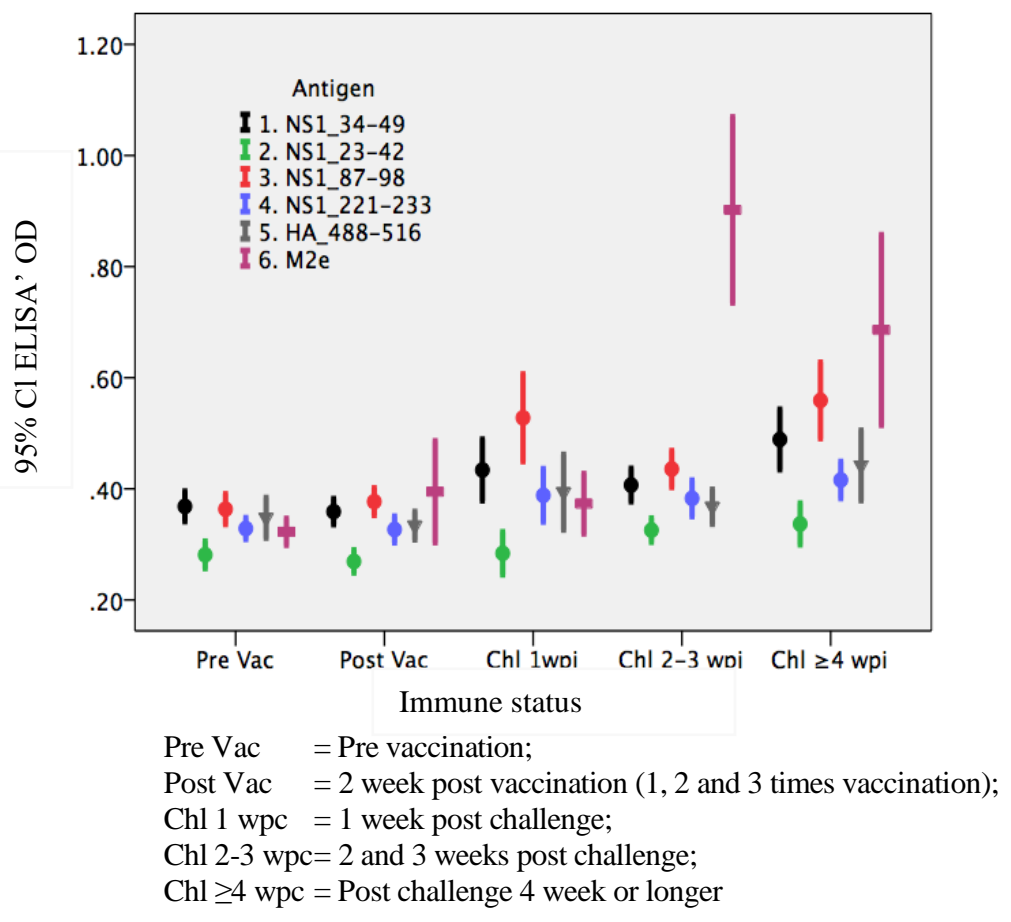

Figure 3. Antibody conversions to NS1, HA2 and M2e peptides in chicken after vaccination and challenge with H5N1 virus

Table 1. Antibody to NS1 (NS1_23-42, NS1_34-49, NS1_87-98, NS1_221-233), HA2 and M2e peptides in chickens that increased significantly $(\mathrm{P}<0.05)$ after challenge with $\mathrm{H} 5 \mathrm{~N} 1 \mathrm{ELISA}$ streptavidin

\begin{tabular}{|c|c|c|c|c|}
\hline & & $\begin{array}{l}1 \text { week post } \\
\text { challenge }\end{array}$ & $\begin{array}{l}2 \text { and } 3 \text { weeks } \\
\text { post challenge }\end{array}$ & $\begin{array}{c}\text { Post } \\
\text { challenge } \\
4 \text { week or } \\
\text { longer }\end{array}$ \\
\hline \multirow{4}{*}{ NS1_23-42 } & Pre vaccination & & $\checkmark$ & $\checkmark$ \\
\hline & 2 week post vaccination (1,2 and 3 times vaccination) & & $\checkmark$ & $\checkmark$ \\
\hline & 1 week post challenge & & & \\
\hline & 2 and 3 weeks post challenge & & & \\
\hline \multirow{4}{*}{ NS1_34-49 } & Pre vaccination & & & $\checkmark$ \\
\hline & 2 week post vaccination (1,2 and 3 times vaccination) & & & $\checkmark$ \\
\hline & 1 week post challenge & & & \\
\hline & 2 and 3 weeks post challenge & & & \\
\hline \multirow{4}{*}{ NS1_87-98 } & Pre vaccination & $\checkmark$ & $\checkmark$ & $\checkmark$ \\
\hline & 2 week post vaccination (1,2 and 3 times vaccination) & $\checkmark$ & & $\checkmark$ \\
\hline & 1 week post challenge & & & \\
\hline & 2 and 3 weeks post challenge & & & $\checkmark$ \\
\hline \multirow{4}{*}{ NS1_221-233 } & Pre vaccination & & $\checkmark$ & $\checkmark$ \\
\hline & 2 week post vaccination (1,2 and 3 times vaccination) & & & $\checkmark$ \\
\hline & 1 week post challenge & & & \\
\hline & 2 and 3 weeks post challenge & & & \\
\hline \multirow{4}{*}{ HA_488-516 } & Pre vaccination & & & $\checkmark$ \\
\hline & 2 week post vaccination (1,2 and 3 times vaccination) & & & $\checkmark$ \\
\hline & 1 week post challenge & & & \\
\hline & 2 and 3 weeks post challenge & & & \\
\hline \multirow{4}{*}{ M2e } & Pre vaccination & & $\checkmark$ & $\checkmark$ \\
\hline & 2 week post vaccination (1,2 and 3 times vaccination) & & $\checkmark$ & $\checkmark$ \\
\hline & 1 week post challenge & & $\checkmark$ & $\checkmark$ \\
\hline & 2 and 3 weeks post challenge & & & \\
\hline
\end{tabular}

$\checkmark=$ Antibody (ELISA OD) was significantly increased $(\mathrm{P}<0.05)$ 
No differences in all antibodies between pre and post-vaccinated sera. The level of antibody to NS1_8798 peptide was significantly higher in the 1-week-postchallenge sera than in pre- and post-vaccinated sera. The higher level at the 1-week-post-challenge sera was not observed in antibody to other peptides, even that to M2e.

\section{Discussions}

This study shows that M2e-based ELISA is superior to NS1- or HA2-based ELISA as DIVA test. As far as we are aware, no study has been carried out previously comparing M2e ELISA and NS1-peptide-based ELISA as DIVA test.

Influenza-NS1 protein consists of 230 amino acids and two functional domains: the RNA-binding (aa residues 1-73) and the effector domain (aa residues 74230). The RNA binding domain funtions to inhibit action of interferon (Donelan et al. 2003; Min \& Krug 2006). The effector domain functions to enhance viral mRNA translation, deregulate cellular mRNA processing, inhibit dsRNA-activated protein kinase and activate phosphoinositide 3-kinase (PI3K) signaling (Hale et al. 2008).

The NS1 protein is the only true non-structural protein in influenza viruses (Donelan et al. 2003). Being the non-structural protein, it is expressed only during viral replication inside the host cells but the protein is not packed into the virion. Driven by the assumption that animals vaccinated with killed AIV vaccines do not develop specific antibodies to the NS1 protein, as do animals infected by life virus, interest in developing a DIVA test based on the NS1 protein has been long present. However, there is still disagreement between different studies on the accuracy of NS1-based ELISA used as DIVA test. Most studies showed that NS1based tests had low accuracy as a DIVA test, as was found in this present studies (Tumpey et al. 2005; Dundon \& Capua 2009; Avellaneda et al. 2010). Other studies, however, indicated that NS1-based ELISA ispotentially useful as DIVA test (Birch-Machin et al. 1997; Ozaki et al. 2001; Tumpey et al. 2005; Takeyama et al. 2011; Wang et al. 2011; Golchinfar et al. 2014). In spite of that potential of NS1-based ELISA as DIVA test, the test had rather low specificity because some vaccinated animals were also seropositive although with low antibody titres. The NS1 antibodies are presumed to be induced by the NS1 protein derived from cellular debris of chicken embryo contaminating the vaccines (Tumpey et al. 2005). The NS1 ELISA has not only low specificity but also low sensitivity. The low sensitivity is associated with the nature of the protein that is poorly immunogenic. The NS1 antibody is usually in low titre and rapidly disappears (Tumpey et al. 2005; Avellaneda et al. 2010). Immune response to NS1 may also be species-dependent. An experimental study reported that infection of chicken with a LPAI isolate caused antibody conversion to NS1 protein only in 3 of 14 birds, and the antibody was detected only at day-3 post infection. Infection of turkey with the same isolate produced higher proportion of seroconversion and the antibody was detected at day-5 to day-10 post infection (Dundon \& Capua 2009).

There are several possible causes of the NS1antibody undetectable in infected chicken. The first possible cause is that the assay used is not sensitive enough to detect the presence of the antibodies. In this present study, four synthetic peptides with amino acid sequence based on the regions of the protein considered to be immunogenic based on hydrophobic analysis. A peptide comparable to that NS1_34-49 in this study has previously been demonstrated to be sensitive when used as coating in ELISA in detecting NS1 antibody (Tumpey et al. 2005). Test based on peptide NS1_23-42 that proceeds at the $\mathrm{N}$-terminal, and overlaps 9 amino acids with NS1_34-49 also failed to detect the presence of NS1 antibody. As a matter of fact, Tumpey et al. 2005 shows that the peptide is more specific, although less sensitive, than the recombinant-whole-NS1 protein. This finding lend support to the opinion that ELISA based on the whole-NS1 protein is not necessary more accurate than that bases on NS1-synthetic peptide in detecting the antibody to the NS1 protein.

The C terminal end of NS1 protein that contain the PDZ-ligand binding motif (PBM), ESEV, has been proven to be immunogenic, and animals infected by influenza viruses become seroconverted to synthetic peptides which sequence is based on the $\mathrm{C}$ terminal part of the NS1 protein (Birch-Machin et al. 1997; Dundon et al. 2006). In this present study, however, the sera from infected birds did not contain antibody to a comparable peptide, NS1_221-233, assayed with the direct-peptide coating ELISA.

Sera from human survived from H5N1-virus infection have been shown to contain antibody to a HA2 peptide, HA_488-516 (Khurana et al. 2011). The antibody reported to be specific for H5N1-virus infection as it was not detected in sera from human vaccinated or infected with seasonal influenza virus, or vaccinated with subunit $\mathrm{H} 5 \mathrm{~N} 1$ vaccine (Khurana et al. 2011). These results suggest that the peptide deem a good candidate for DIVA test in poultry. However, our study showed that the infected birds failed to be positively converted to the same HA_488-516 peptide.

It is not only the peptides themselves, the ELISA format, the direct coatingof peptides onto the wells of ELISA plates, used in this study was also similar to the previous studies (Tumpey et al. 2005; Dundon et al. 2006). Therefore, the probability that the peptides were notimmobilised on the microtitre plate as the cause of the failure to detect the NS1 antibody in sera of 
challenged birds in our study seems unlikely. This possibility was partially ruled out by the streptavidinpeptide ELISA. The streptavidin coated onto the plates has been shown to specifically bind to biotinyl substances. Since the peptides used were all biotinylated at the $\mathrm{N}$ terminal, the peptide were expected tobind to the plate only through its $\mathrm{N}$-terminal 'tip'; consequently, if asample serum contains NS1 antibody, it should react with the immobilised peptide efficiently. The fact that the ELISA's ODs of challenged sera increased significantly as compared to those before challenge indicated that the streptavidinpeptide coated ELISA is more sensitive than the directpeptide coated ELISA. Since the increased were only slight even in the improved assay, it indicates that the conversion of antibody to NS1 protein in the infected birds is only mild and only detected by a very sensitive assay.

In summary, this study shows that antibody to either M2e, HA_488-516, NS1 peptides, are absent in bird naïve or vaccinated with killed $\mathrm{H} 5 \mathrm{~N} 1$ vaccines. Antibody conversion to M2e is more consistent and its magnitude is much higher than that to HA_488-516 and peptide NS1 peptides. Consequently, M2e-based is much more reliable than NS1- or HA2-based ELISA as DIVA test. Antibody conversion to HA_488-516 and peptide NS1 in infected chickens is extremely mild and therefore difficult to detect.

\section{ACKNOWLEDGEMENTS}

This work was supported in part by a grant from the Australian Centre for International Agricultural Research AH/2010/039. The authors thank Mrs Gita Sekarmila and Mr Achpas for technical assistance.

\section{REFERENCES}

Avellaneda G, Mundt E, Lee CW, Jadhao S, Suarez DL. 2010. Differentiation of infected and vaccinated animals (DIVA) using the NS1 protein of avian influenza virus. Avian Dis. 54:278-286.

Birch-Machin I, Rowan A, Pick J, Mumford J, Binns M. 1997. Expression of the non-structural protein NS1 of equine influenza A virus: detection of anti-NS1 antibody in post infection equine sera. J Virol Methods. 65:255-263.

Capua I, Terregino C, Cattoli G, Mutinelli F, Rodriguez JF. 2003. Development of a DIVA (Differentiating Infected from Vaccinated Animals) strategy using a vaccine containing a heterologous neuraminidase for the control of avian influenza. Avian Pathol. 32:47-55.

Capua I, Cattoli G, Marangon S. 2004. DIVA--a vaccination strategy enabling the detection of field exposure to avian influenza. Dev Biol. 119:229-233.
Donelan NR, Basler CF, Garcia-Sastre A. 2003. A recombinant influenza A virus expressing an RNAbinding-defective NS1 protein induces high levels of beta interferon and is attenuated in mice. $\mathrm{J}$ Virol. 77:13257-13266.

Dundon WG, Milani A, Cattoli G, Capua I. 2006. Progressive truncation of the Non-Structural 1 gene of H7N1 avian influenza viruses following extensive circulation in poultry. Virus Res. 119:171-176.

Dundon WG, Capua I. 2009. A closer look at the NS1 of influenza virus. Viruses. 1:1057-1072.

Golchinfar F, Madani R, Emami T, Pourbakhsh S, Shoushtary A. 2014. Applying conserved peptides of NS1 protein of avian influenza virus to differentiate infected from vaccinated chickens. Arch Razi Institute. 69:41-45.

Hadifar FJ, Ignjatovic, Tarigan S, Indriani R, Ebrahimie E, Hasan NH, McWhorter A, Putland S, Ownagh A, Hemmatzadeh F. 2014. Multimeric recombinant M2e Protein-Based ELISA: A significant improvement in differentiating avian influenza infected chickens from vaccinated ones. PloS One. 9:e108420.

Hale BG, Barclay WS, Randall RE, Russell RJ. 2008. Structure of an avian influenza A virus NS1 protein effector domain. Virol. 378:1-5.

Hemmatzadeh F, Sumarningsih S, Tarigan S, Indriani R, Dharmayanti NLPI, Ebrahimie E, Ignjatovic J. 2013. Recombinant M2e protein-based ELISA: a novel and inexpensive approach for differentiating avian influenza infected chickens from vaccinated ones. PloS One. 8:e56801.

Khurana S, Sasono P, Fox A, Nguyen VK, Le QM, Pham QT, Nguyen TH, Nguyen TL, Horby P, Golding H. 2011. H5N1-SeroDetect EIA and rapid test: a novel differential diagnostic assay for serodiagnosis of H5N1 infections and surveillance. J Virol. 85:12455-12463.

Kim MC, Choi JG, Kwon JS, Kang HM, Paek MR, Jeong OM, Kwon JH, Lee YJ. 2010. Field application of the H9M2e enzyme-linked immunosorbent assay for differentiation of H9N2 avian influenza virus-infected chickens from vaccinated chickens. Clin Vac Immunol. 17:1977-1984.

Lambrecht B, Steensels M, Van Borm S, Meulemans G, van den Berg T. 2007. Development of an M2e-specific enzyme-linked immunosorbent assay for differentiating infected from vaccinated animals. Avian Dis. 51:221226.

Min JY, Krug RM. 2006. The primary function of RNA binding by the influenza A virus NS1 protein in infected cells: Inhibiting the 2'-5' oligo (A) synthetase/RNase L pathway. Proc Natl Acad Sci. 103:7100-7105.

Ozaki H, Sugiura T, Sugita T, Imagawa H, Kida H. 2001. Detection of antibodies to the nonstructural protein (NS1) of influenza A virus allows distinction between vaccinated and infected horses. Vet Microbiol. 82:111119. 
Savill NJ, St.Rose SG, Keeling MJ, Woolhouse ME. 2006. Silent spread of H5N1 in vaccinated poultry. Nature. 442:757.

Suarez DL. 2005. Overview of avian influenza DIVA test strategies. Biologicals: J Int Assoc Biol Stand. 33:221226.

Takeyama N, Minari K, Kajihara M, Isoda N, Sakamoto R, Sasaki T, Kokumai N, Takikawa N, Shiraishi R, Mase M, Hagiwara J, Kodama T, Imamura T, Sakaguchi M, Ohgitani T, Sawata A, Okamatsu M, Muramatsu M, Tsukamoto K, Lin Z, Tuchiya K, Sakoda Y, Kida H. 2011. Detection of highly pathogenic avian influenza virus infection in vaccinated chicken flocks by monitoring antibodies against non-structural protein 1 (NS1). Vet Microbiol. 147:283-291.

Tarigan S, Sumarningsih. 2014. Production and purification of streptavidin with higher biotin-binding activity. JITV. 19:231-238

Tarigan S. 2015. Infeksi subklinis virus avian influenza H5N1 pada peternakan ayam yang menerapkan program vaksinasi (subclinical infection by avian influenza H5N1 virus in vaccinated poultry). Wartazoa. 25:75-84.

Tarigan S, Indriani R, Durr PA, Ignjatovic J. 2015. Characterization of the M2e antibody response following highly pathogenic $\mathrm{H} 5 \mathrm{~N} 1$ avian influenza virus infection and reliability of M2e ELISA for identifying infected among vaccinated chickens. Avian Pathol. 44:259-268

Tumpey TM, Alvarez R, Swayne DE, Suarez DL. 2005. Diagnostic approach for differentiating infected from vaccinated poultry on the basis of antibodies to NS1, the nonstructural protein of influenza A virus. J Clin Microbiol. 43:676-683.

Wang L, Qin Z, Pantin-Jackwood M, Faulkner O, Suarez DL, Garcia M, Lupiani B, Ready SM, Saif YM, Lee CW. 2011. Development of DIVA (differentiation of infected from vaccinated animals) vaccines utilizing heterologous NA and NS1 protein strategies for the control of triple reassortant $\mathrm{H} 3 \mathrm{~N} 2$ influenza in turkeys. Vaccine. 29:7966-7974. 